\title{
This is your journal Europe!
}

The European Journal of Anaesthesiology has grown up today, 1 January 1999, with the start of monthly publications. The journal started its life in March 1984 under the constructive and imaginative editorship of Professor Michael Vickers. Initially, it appeared twice a year and progressed to four times and then to six times a year. During the past 4 years, the journal layout has changed, editorials have been introduced and the correspondence section is slowly becoming more active.

The growing success of the journal reflects the dedicated work of the editors, whose names are listed inside the cover, and the referees, whose enthusiasms guide the editors as they make their decision about the suitability of the manuscripts for publication. The experience of the publishers, Blackwell Science, has been a valuable resource to draw upon.

Our continent encapsulates in glory all that is flawless in architecture, in art, in music and in literature. It was in Europe that science first quickened. Science, the engine of the great changes that have so altered the lives of our generation, has brought a prospect of wealth and prosperity for all that our forefathers could not imagine. However, our history has also been one of discord. There have been tensions resulting from language, cultural perspectives and religion. The storms of war have continued through century after century to cause our continent to weep. Even now, as I write, the machines of war are stirring yet again, in readiness for their task to kill and maim without pity.

The history of our extraordinarily beautiful continent has been one of dissonance, but this journal, by providing a common intellectual outlet for the anaesthetic endeavours of European anaesthetists, completes one European dream, that of unity of purpose. Within the European Academy, anaesthetists from all the countries in Europe are crossing their national boundaries and sharing their knowledge and their experiences and, by using this currency of knowledge and experience, they are able to share something even more important, they are sharing friendship. We are beginning to share our continent!

The European Journal of Anaesthesiology documents our work as a permanent history of progress in anaesthesia that even transcends the continent's own borders, linking European anaesthetists with those others, some as fortunate, some less fortunate, but all with similar interests and problems scattered around our world. The European Academy continues to strengthen the bond between anaesthetists across our continent and the European Journal of Anaesthesiology continues to grow, reflecting the best European anaesthetic practice and research.

This is your journal Europe!

As the New Year commences, the last before the third millennium commences, I am grateful to the editors and the referees. We welcome Professor Christian Werner from Munich and wish him much pleasure as a member of our editorial team.

A Happy New Year to Europe and to you all.

Professor T. E. J. Healy Editor in Chief

Accepted October 1998 